Annals of International Medical and Dental Research

E-ISSN: 2395-2822 | P-ISSN: 2395-2814

Vol-8, Issue-2 | March-April 2022

DOI: 10.53339/aimdr.2022.8.2.19

Page no- 135-144 | Section- Research Article (Haematology)

\title{
Predictors of Initial Glaucoma Therapy: Laser Trabeculoplasty Versus Medication
}

\section{Zakia Sultana Shahid1*, M. Nazrul Islam², Ishtiaque Anwar ${ }^{3}$}

1Glaucoma Specialist, Faculty, Anwer Khan Modern Medical College, Dhaka, Bangladesh. Orcid: 0000-0001-3855-9809

2Chairman, Glaucoma Faculty, Bangladesh Eye Hospital \& Institute, Dhaka, Bangladesh.

Orcid: 0000-0001-9630-5834

${ }^{3}$ Assistant Professor, Bangladesh Eye Hospital \& Institute, Dhaka, Bangladesh. Orcid: 0000-0002-6649-0511

*Corresponding author

\begin{abstract}
Background: Glaucoma is the most common cause of blindness in the world. If not recognized and treated early enough, open-angle glaucoma can be a severe ocular illness that can lead to blindness. A gradual loss of ganglion cells leads to the optic nerve head cupping, which is the pathogenic process. Objective: The main aim of this study was to determine if selective laser trabeculoplasty (SLT) is superior to topical medication as the first-line treatment for open-angle glaucoma. Material \& Methods: This prospective comparative study was conducted in 225 patients (450 eyes) at Deen Mohd. Eye Hospital \& Research Center from July 2019 to July 2021.The patients were randomly divided into two groups; Selective laser trabeculoplasty (SLT group)and medical therapy group. Results: The study was conducted between 25 to 85 years of patients where the majority were between 46 to 65 years age group; $58 \%$ patientswere male, and $42 \%$ were female. The mean intraocular pressure (IOP) was $18.2 \mathrm{~mm} \mathrm{Hg}$ for the SLT group and $17.6 \mathrm{~mm}$ $\mathrm{Hg}$ for the medical therapy group. Overall, mean pressures and IOP lowering were not statistically different between the two treatment groups. Conclusions: In the last follow-up, $11 \%$ of the eyes had been stepped to additional SLT in the SLT arm, and $27 \%$ of the eyes in the medical arm required more medications to reach the target IOP range. The main risk factor is high intraocular pressure; however additional potential risk factors include optic nerve vascular insufficiency, neuronal degeneration, and hereditary factors. More research and prospective trials on intraocular pressure control and disease progression are needed to understand the longterm implications.
\end{abstract}

Received: 21 December 2021

Revised: 28 January 2022

Accepted: 06 February 2022

Published: 18 February 2022

Keywords:- Glaucoma therapy, Laser trabeculoplasty, Open-angle glaucoma, intraocular pressure.

\section{INTRODUCTION}

Glaucoma is one of the world's most common causes of irreversible blindness.[1] In 2010, more than 60 million people were affected, with 8.4 million of them becoming blind on both sides due to the disease. Glaucoma will affect 79.6 million individuals worldwide in 1012 years, with $74 \%$ of those suffering from open-angle glaucoma (OAG).[2] The goal of
OAG therapy is to keep the optic nerve healthy by lowering IOP. There are now three options for achieving this goal: medicines, laser treatments, and surgery.[3] Medication is usually the first line of defense when it comes to lowering IOP.For regulating IOP, a variety of potently hypotensive topical medications is currently available.[4] 
Annals of International Medical and Dental Research E-ISSN: 2395-2822 | P-ISSN: 2395-2814

Vol-8, Issue-2 | March-April 2022

DOI: 10.53339/aimdr.2022.8.2.19

Page no- 135-144 | Section- Research Article (Haematology)

On the other hand, medication has several possible drawbacks, both in the drug itself and its preservatives. Patients must bear the expenditures of continued medical care, as well as the adverse effects of medications and the need for frequent application. [5] Selective laser trabeculoplasty (SLT) was introduced as a new non-invasive option for lowering IOP in eyes with OAG.6] This treatment involves placing laser spots in the trabecular meshwork, which causes an increase in outflow capacity and, as a result, a decrease in IOP. In a recent Cochrane systematic review of laser trabeculoplasty, only one trial comparing SLT to medicine was included, preventing a metaanalysis at the time.[3] In a recent meta-analysis comparing SLT with argon laser trabeculoplasty (ALT) in the treatment of OAG, the role of medication was not assessed.[7] As a result, SLT is more dependable than conventional medications.Despite the introduction and widespread usage of beneficial drugs such as topical prostaglandin analogs, beta-blockers, alpha-agonists, and carbonic anhydrase inhibitors, a quarter of patients treated for 20 years have progressed to blindness in one eye.[8] Patients with glaucoma can go blind for various causes, one of which is failure to follow medical treatment instructions. Electronic monitoring and evaluating prescription refill rates show that many individuals do not take their medications as prescribed. [9,10] Non-adherence can be due to various factors, including forgetfulness, physical incapacity to position eye drops, medicine side effects, health views, and the expense of medication. In 2004, the total cost of care for glaucoma patients was estimated to be $\$ 2.9$ billion, with most of the money going on pharmaceuticals and outpatient treatments.[11]

The use of laser trabeculoplasty or trabeculectomy in the treatment of glaucoma has been demonstrated in several trials. Both the Glaucoma Laser Trial (GLT) and the Collaborative Initial Glaucoma Treatment Study were large National Eye Institute prospective multicenter trials that compared initial medical therapy with laser trabeculoplasty and trabeculectomy (CIGTS). [6,7,8] IOP therapy with laser trabeculoplasty or trabeculectomy was as successful in maintaining IOP reduction as a single medication.Other lasers have been researched for angle applications since Wise and Witter presented argon laser trabeculoplasty (ALT) for the treatment of OAG.[9,10] The use of a frequency-doubled $\mathrm{Nd}$ :YAG laser, whose wavelength enables for selective photothermolysis of melanin while preserving non-pigmented tissue, was defined by Latina and Park.[11] A scanning electron microscope investigation revealed that the selective laser caused no thermal harm when aimed at the trabecular meshwork of human cadaver eyes, in contrast to the usual thermal melt found when pointing the argon laser at the trabecular meshwork of human cadaver eyes.112] Patients uncontrolled by medicinal treatment had an additional reduction in IOP in the initial clinical studies with selective laser trabeculoplasty (SLT). $\underline{13,14,15,16,17,18]}$

\section{Objective}

The main objective of this trial was to see whether selective laser trabeculoplasty (SLT) is a better first-line treatment for open-angle glaucoma than topical medicine. 
Annals of International Medical and Dental Research

E-ISSN: 2395-2822 | P-ISSN: 2395-2814

Vol-8, Issue-2 | March-April 2022

DOI: 10.53339/aimdr.2022.8.2.19

Page no- 135-144 | Section- Research Article (Haematology)

\section{MATERIAL AND METHODS}

A total of 225 patients were included in thisprospective comparative study. In this study, the patients were randomly divided into two groups (either the SLT group or topical medical therapy group). Table 1 shows the study design specifically.

Table 1: Study design

\begin{tabular}{|c|c|c|}
\hline Type of Study & Place of Study & Period of study \\
\hline $\begin{array}{l}\text { A } \quad \text { prospective } \\
\text { comparative study. }\end{array}$ & Deen Mohd. Eye Hospital \& Research Center & July 2019 to July 2021 \\
\hline
\end{tabular}

\section{Sample size:}

This prospective comparative study was conducted on a total of 225 patients (450 eyes).

SLT group: 119 patients (238 eyes)

Medicine/Drop group (topical medical therapy):106 patients (212 eyes)

\section{Inclusion criteria}

- Patients between 35-85 years of age with IOP $\geq 24$ and $\leq 31$

- Diagnosis of primary OAG (Mild/Moderate)not yet used any antiglaucoma drop

- OAG uncontrolled on medical treatment with 1 or 2 drops

- Pseudoexfoliation glaucoma

- Pigmentary OAG

- Diagnosis of ocular hypertension

- No previous intraocular surgery

- Pregnant woman with OAG

\section{Exclusion criteria}

- Patients on >2 glaucoma medications

- Had a CIGTS visual field score that exceeded 16 in either eye.

- Evidence of ocular disease other than glaucoma or ocular hypertension.
- Diagnosis of OAG with proliferative diabetic retinopathy

\section{Data collection:}

A group of clinicians gathered medical records by interviewing patients directly after obtaining written informed consent and hospital records.

\section{Statistical analysis:}

All statistical analysis was carried out using excel and SPSS (Statistical Program for scientific study) version 25 statistical packageanalysis tool. Frequency and percentages are presented for the categorical variables, and mean \pm standard deviation and median are given for the continuous variables. P-value $<0.05$ was considered significant in our study.

\section{RESULTS}

A total of 225 patients (450 eyes) was enrolled in this study, and180 patients reached the 20 to 24-months follow-up window. The remaining 45 patients were not included in this analysis because they had not reached the time endpoint at the termination of the study. The data regarding the rate of marital status, glaucoma in the immediate family, glaucoma 
Annals of International Medical and Dental Research

E-ISSN: 2395-2822 | P-ISSN: 2395-2814

Vol-8, Issue-2 | March-April 2022

DOI: 10.53339/aimdr.2022.8.2.19

Page no- 135-144 | Section- Research Article (Haematology)

in the distant family, hypertension, diabetes, and smoking historyof patients were included here. [Table 2] shows the demographic data of all the patients.

Table 2: Demographic data of the patients

\begin{tabular}{|c|c|c|c|c|c|}
\hline \multirow[t]{2}{*}{ Variables } & \multicolumn{2}{|c|}{ Medicine group $(n=106)$} & \multicolumn{2}{|c|}{ SLT group $(n=119)$} & \multirow[t]{2}{*}{ Pvalue } \\
\hline & Frequency & Percentage $(\%)$ & Frequency & $\begin{array}{l}\text { Percentage } \\
(\%)\end{array}$ & \\
\hline \multicolumn{5}{|l|}{ Material status } & \\
\hline Married & 63 & $28 \%$ & 60 & $50.42 \%$ & \multirow[t]{2}{*}{0.31} \\
\hline Unmarried & 43 & $19.1 \%$ & 59 & $49.58 \%$ & \\
\hline \multicolumn{5}{|c|}{ Glaucoma in the immediate family } & \\
\hline Yes & 45 & $42.45 \%$ & 58 & $48.74 \%$ & \multirow[t]{2}{*}{0.67} \\
\hline No & 61 & $57.55 \%$ & 61 & $51.26 \%$ & \\
\hline \multicolumn{5}{|c|}{ Glaucoma in distant family } & \\
\hline Yes & 30 & $28.30 \%$ & 50 & $42.02 \%$ & \multirow[t]{2}{*}{0.89} \\
\hline No & 76 & $77.70 \%$ & 69 & $57.98 \%$ & \\
\hline \multicolumn{5}{|l|}{ Hypertension } & \\
\hline Yes & 31 & $29.25 \%$ & 36 & $30.25 \%$ & \multirow[t]{2}{*}{0.75} \\
\hline No & 75 & $70.75 \%$ & 83 & $69.75 \%$ & \\
\hline \multicolumn{5}{|l|}{ Diabetes } & \\
\hline Yes & 35 & $33.02 \%$ & 12 & $10.08 \%$ & \multirow[t]{2}{*}{0.83} \\
\hline No & 71 & $66.98 \%$ & 107 & $89.92 \%$ & \\
\hline \multicolumn{5}{|l|}{ Smoking history } & \\
\hline Current smoker & 7 & $6.60 \%$ & 19 & $15.97 \%$ & \multirow[t]{3}{*}{0.02} \\
\hline Ex-smoker & 18 & $16.98 \%$ & 35 & $29.41 \%$ & \\
\hline Never & 81 & $76.42 \%$ & 65 & $54.62 \%$ & \\
\hline
\end{tabular}

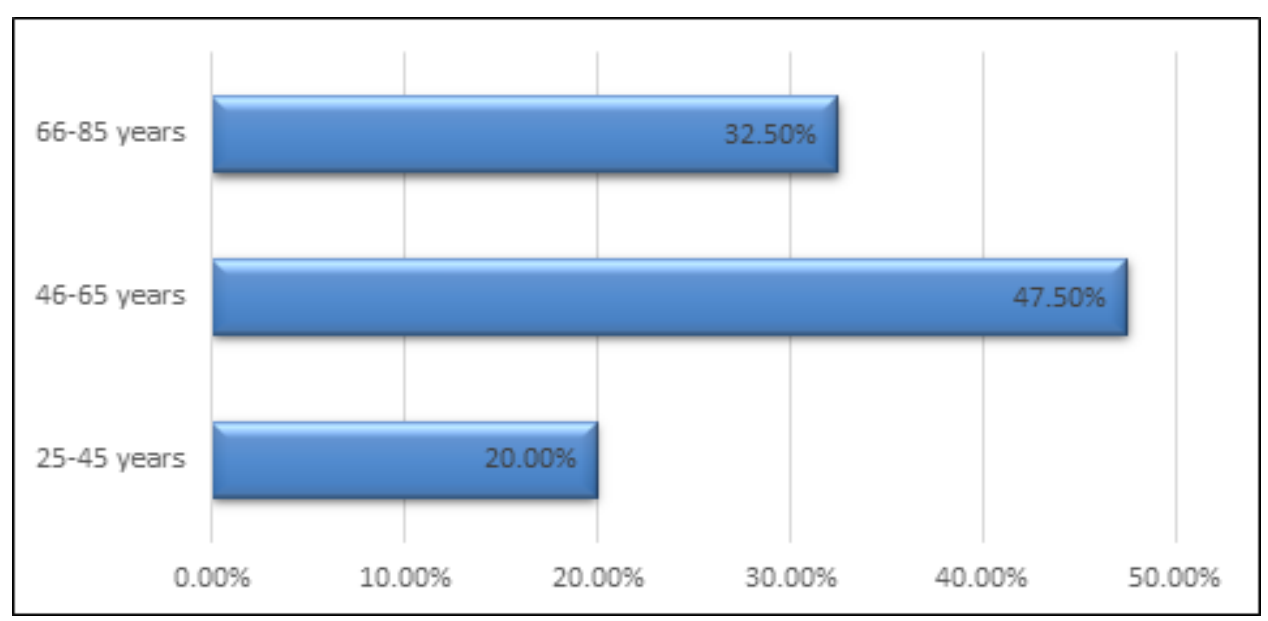

Figure 1: Distribution of age group among the patients. 
Patients included in this study were between 25-85 years of age [Figure 1]. The majority of the patients belong to the 46-65 years age group. Moreover, the least amount of patients was from the 2545years of age range. The mean and Standard deviation of the patients was 62.4 \pm 10.9 .

[Figure 2] Shows that among the 225 patients, 58\% (130) were male, and 42\% (95) were female.

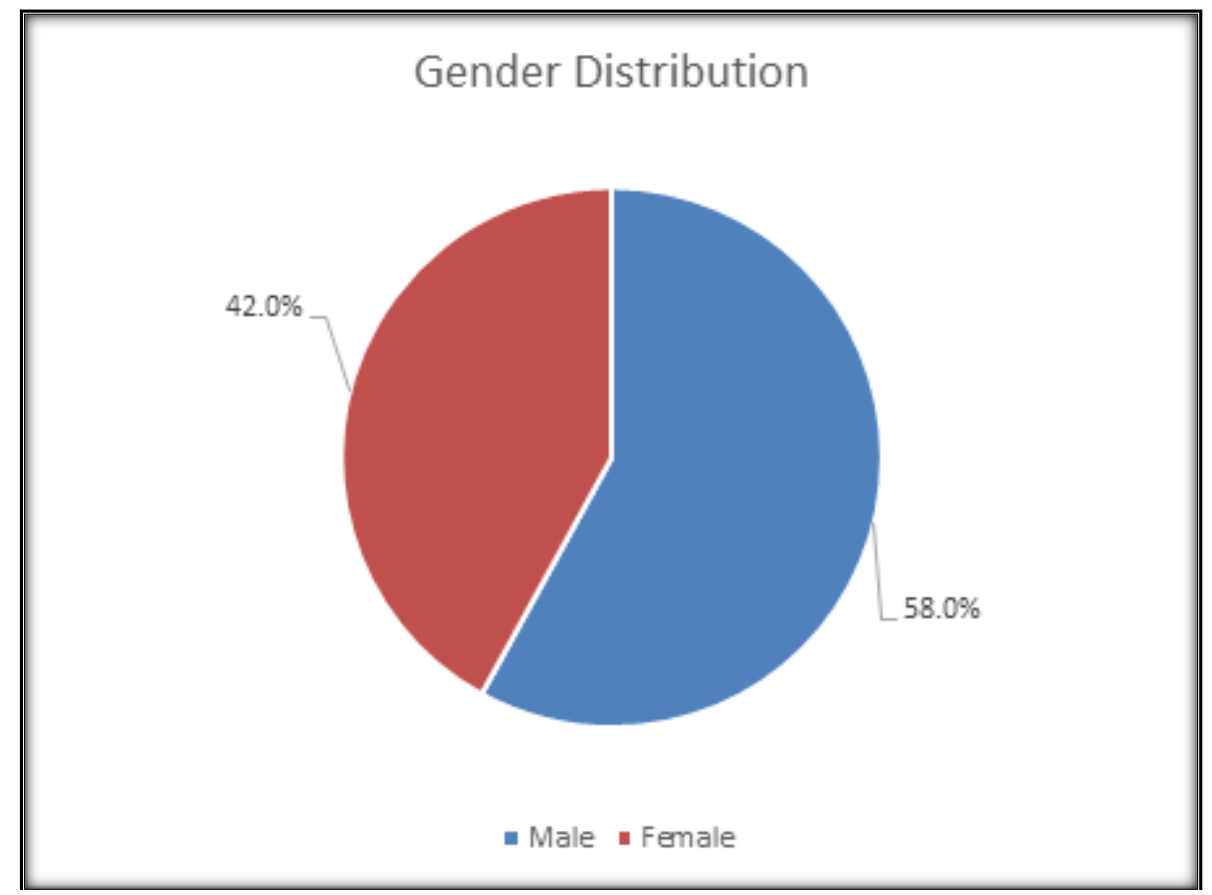

Figure 2: Gender distribution of the patients.

[Table 3] shows the follow-up results for all the 225 patients enrolled in this study. Including those, 45 reached 4 to 6 months follow-up, and 180 patients reached 9 to 12 months of follow-up.

Table 3: Changes of IOP at baseline and follow-up

\begin{tabular}{|l|l|l|l|}
\hline Variables & Baseline & Follow-up (4 to 6 months) & Follow-up (9-12 months) \\
\hline Medicine group & 22.9 & 19.2 & 18.8 \\
\hline Left eye & 22.6 & 18.6 & 17.9 \\
\hline Right eye & \multicolumn{2}{l|}{} \\
\hline \multicolumn{5}{|l|}{} & 20.2 & 19.5 \\
\hline SLT group & 23.4 & 19.9 & 19.3 \\
\hline Left eye & 25.7 & & \\
\hline Right eye &
\end{tabular}

[Table 4] shows the overall mean IOP for both eyes at baseline for the SLT and medical groups, 25.2 and $24.6 \mathrm{~mm} \mathrm{Hg}$, respectively. In addition, at the 6 and 12-month follow-up periods, the mean IOP for both eyes for each treatment group is shown. The mean pressure in the SLT group was $18.2 \mathrm{~mm} \mathrm{Hg}$ 
Annals of International Medical and Dental Research E-ISSN: 2395-2822 | P-ISSN: 2395-2814

Vol-8, Issue-2 | March-April 2022

DOI: 10.53339/aimdr.2022.8.2.19

Page no- 135-144 | Section- Research Article (Haematology)

(6.3mm $\mathrm{Hg}$ reduction) at the last visit, while in the medical arm, it was $17.6 \mathrm{~mm} \mathrm{Hg}(7.0 \mathrm{~mm} \mathrm{Hg}$ reduction). Overall mean pressures and IOP reduction did not differ statistically between the two treatment groups.

Table 4: Changes of IOP at baseline and follow-up

\begin{tabular}{|l|l|l|l|}
\hline Variables & Baseline & Follow-up (4 to 6 months) & Follow-up (9-12 months) \\
\hline Medicine group & $24.6( \pm 2)$ & $17.9( \pm 3.1)$ & $17.6( \pm 2.9)$ \\
\hline IOP & & $6.4( \pm 2.5)$ & $7.1( \pm 1.9)$ \\
\hline IOP change & $5.8( \pm 1.2)$ & $11.5( \pm 0.7)$ \\
\hline Months of follow up & \multicolumn{5}{|l|}{} \\
\hline SLT group & $25.2( \pm 2.1)$ & $18.8( \pm 2.7)$ & $18.2( \pm 2.9)$ \\
\hline IOP & $6.1( \pm 3.2)$ & $6.3( \pm 2.6)$ \\
\hline IOP change & $6.7( \pm 1.0)$ & $12.3( \pm 1.7)$ \\
\hline Months of follow up & & &
\end{tabular}

The number of treatment steps and the percentage of eyes that met the target IOP values are shown in [Table 5]. By the last follow-up, 11\% of the eyes in the SLT arm had been stepped up to more SLT, whereas $27 \%$ of the eyes in the medical arm needed extra medicines to meet the target IOP range.

Table 5: Distribution of Number of Steps by Treatment Group

\begin{tabular}{|l|l|l|l|l|}
\hline \multirow{2}{*}{ Variables } & 4 to 6 months & \multicolumn{2}{l|}{ 9 to 12 months } \\
\cline { 2 - 5 } & Medicine group & SLT group & Medicine group & SLT group \\
\hline Single treatment & 90 & 103 & 72 & 83 \\
\hline Double treatment & 11 & 9 & 7 & 9 \\
\hline Double treatment in the left eye only & 3 & 0 & 1 & 2 \\
\hline Double treatment in right eye only & 2 & 6 & 0 & 4 \\
\hline Triple treatment & 0 & 1 & 0 & 2 \\
\hline Percentage met target IOP & \multicolumn{5}{|l}{} \\
\hline Right eye & $126(56 \%)$ & $106(47 \%)$ & $126(70 \%)$ & $103(57 \%)$ \\
\hline Left eye & $97(43 \%)$ & $108(48 \%)$ & $111(62 \%)$ & $97(54 \%)$ \\
\hline
\end{tabular}

\section{DISCUSSION}

There are several concerns about chronic medical treatment for glaucoma:

1. Suspected lack of medication adherence;

2. Glaucoma drug side effects;
3. Wide variations in IOP due to trough effects or not using drugs at appropriate times; and

4. Worsening the guess of glaucoma surgery due to ocular surface-induced changes.

A variety of studies using a questionnaire, electronic surveillance, and persistency refill data have convincingly demonstrated 
Annals of International Medical and Dental Research E-ISSN: 2395-2822 | P-ISSN: 2395-2814

Vol-8, Issue-2 | March-April 2022

DOI: 10.53339/aimdr.2022.8.2.19

Page no- 135-144 | Section- Research Article (Haematology)

widespread noncompliance with glaucoma medication therapy. ${ }^{[8,9]}$ Many glaucoma patients have minimal adherence to medical treatment, prompting physicians to devise ways to improve compliance by selecting welltolerated medications, $[23,24,25,26]$ limiting dose schedules, simplifying drug regimens, and offering patient education and reinforcement.Concern has been expressed about ocular surface modification resulting from long-term glaucoma drug administration, which could compromise drug tolerance and filtration surgical success. 27,28$]$ Several prospective randomized trials, including the Advanced Glaucoma Intervention Study, [29] the CIGTS,[8] and the GLT, [6,7] have called into question the traditional treatment paradigm for OAG. The possibility of using ALT as an initial treatment rather than conventional medical treatment was investigated in the latter trial.

The destructive thermal action of ALT on the trabecular meshwork, which destroys the outflow mechanism in the vicinity of each thermal, coagulative ALT application, has been identified as a source of concern. This could have long-term consequences for illness progression and response to medical treatment. Due to the poor response to repeat ALT and concerns about thermal injuryinduced scarring of the outflow system, $[30,31]$ various laser wavelengths for trabeculoplasty have been investigated, such as the frequencydoubled Nd:YAG (SLT) laser.In human tissue studied with a scanning electron microscope, SLT has no detectable thermal effects compared to ALT.112] SLT, unlike many other therapies that do not address the underlying pathophysiology of OAG, is thought to renew the trabecular meshwork and enhance outflow.[32]

Patients were randomly assigned to either SLT or pharmacological therapy in this trial, removing any concerns about glaucoma medicines having cross-over effects. At the last follow-up visit, the SLT group had lowered IOP $26.4 \%$, and the medicinal arm had lowered IOP $27.8 \%$, indicating that the two groups' efficacy was equivalent. The goal of this study was to track the effects of IOP decreasing for a year. Previous studies have compared SLT and ALT as supplementary therapy to medicines in a retrospective study and prospective series, $20,21,22]$ all of which concluded that they were equally effective.SLT has recently been employed as the principal therapy in three prospective studies, $[33,34]$ with IOP reductions of roughly $30 \%$ below untreated baseline levels, comparable to prostaglandin reductions of IOP. Melamed et al.[33] and McIlraith et al.[35] reported an $8 \mathrm{~mm} \mathrm{Hg}$ drop in IOP with SLT in their nonrandomized investigations.

In their study, Matthew P Quinn et al. included 194759 patients. Women were more likely than men to be treated with LT rather than medication (81 years of age vs. 66-70 years of age: OR, 0.49; 95\% confidence interval [CI], 0.48-0.50), while older patients were less likely to be treated with $\mathrm{LT}$ rather than medication (81 years of age vs. 66-70 years of age: OR, 0.49; 95\% confidence interval [CI], 0.48-0.50). (OR, $1.42 ; 95 \% \mathrm{CI}, 1.39-1.45)$. Cataract surgery (OR, $0.31 ; 95 \% \mathrm{CI}, 0.30-0.32)$, corneal transplantation (OR, 0.39; 95\% CI, 0.31-0.49), and retina surgery (OR, 0.39; 95\% CI, 0.31-0.49) were also linked to a lower likelihood of receiving LT treatment (OR, 0.46; 95\% CI, 0.41-0.51). Patients who had many comorbidities were less likely 
Annals of International Medical and Dental Research

E-ISSN: 2395-2822 | P-ISSN: 2395-2814

Vol-8, Issue-2 | March-April 2022

DOI: 10.53339/aimdr.2022.8.2.19

Page no- 135-144 | Section- Research Article (Haematology)

to get LT (highest vs. lowest level of comorbidity: OR, 0.94; 95\% CI, 0.91-0.97). Patients with a higher SES (highest vs. lowest level: OR, 0.86; 95\% CI, 0.84-0.89) and who lived in a rural area were less likely to use laser trabeculoplasty (versus urban: OR, 0.92; 95\% CI, 0.90-0.95). Over time, there has been an increase in LT use (for each additional calendar year: OR, 1.05 per year; 95\% CI, 1.05-1.05 per year)..$\underline{36]}$

\section{CONCLUSIONS}

The efficacy of initial laser trabeculoplasty treatment was comparable to that of initial

\section{REFERENCES}

1. Congdon N, O'Colmain B, Klaver CC, Klein R, Muñoz B, Friedman DS, et al; Eye Diseases Prevalence Research Group. Causes and prevalence of visual impairment among adults in the United States. Arch Ophthalmol. 2004;122(4):477-85. doi: 10.1001/archopht.122.4.477.

2. Hattenhauer MG, Johnson DH, Ing HH, Herman DC, Hodge DO, Yawn BP, et al. The probability of blindness from open-angle glaucoma. Ophthalmology. 1998;105(11):2099-104. doi: 10.1016/S0161-6420(98)91133-2.

3. Kass MA, Gordon M, Morley RE Jr, Meltzer DW, Goldberg JJ. Compliance with topical timolol treatment. Am J Ophthalmol. 1987;103(2):188-93. doi: 10.1016/s0002-9394(14)74225-4.

4. Schwartz GF, Reardon G, Mozaffari E. Persistency with latanoprost or timolol in primary open-angle glaucoma suspects. Am J Ophthalmol. 2004;137(1 Suppl):S13-6. doi: 10.1016/j.ajo.2003.10.034.

5. Rein DB, Zhang P, Wirth KE, Lee PP, Hoerger TJ, McCall N, et al. The economic burden of major adult visual disorders in the United States. Arch Ophthalmol. 2006;124(12):1754-60. doi: 10.1001/archopht.124.12.1754.

6. The Glaucoma Laser Trial (GLT). 2. Results of argon laser trabeculoplasty versus topical medicines. The topical drug treatment. SLT, we feel, is a safe and well-tolerated outpatient technique for decreasing IOP sufficiently in chosen individuals with OAG. The main risk factor is high intraocular pressure; however additional potential risk factors include optic nerve vascular insufficiency, neuronal degeneration, and hereditary factors.In a long-term follow-up prospective clinical investigation, the duration of the IOP-lowering impact must be studied. Because glaucoma is a chronic condition, longer-term outcome data will be required to create the basis for particular therapy recommendations.

Glaucoma Laser Trial Research Group. Ophthalmology. 1990;97(11):1403-13.

7. The Glaucoma Laser Trial (GLT) and glaucoma laser trial follow-up study: 7. Results. Glaucoma Laser Trial Research Group. Am J Ophthalmol. 1995;120(6):718-31. doi: 10.1016/s0002-9394(14)727254.

8. Lichter PR, Musch DC, Gillespie BW, Guire KE, Janz NK, Wren PA, Mills RP; CIGTS Study Group. Interim clinical outcomes in the Collaborative Initial Glaucoma Treatment Study comparing initial treatment randomized to medications or surgery. Ophthalmology. 2001;108(11):1943-53. doi: 10.1016/s0161-6420(01)00873-9.

9. Wise JB, Witter SL. Argon laser therapy for openangle glaucoma. A pilot study. Arch Ophthalmol. 1979;97(2):319-22.

doi: 10.1001/archopht.1979.01020010165017.

10. Wise JB. Long-term control of adult open angle glaucoma by argon laser treatment. Ophthalmology. 1981;88(3):197-202. doi: 10.1016/s0161-6420(81)350490.

11. Latina MA, Park C. Selective targeting of trabecular meshwork cells: in vitro studies of pulsed and CW laser interactions. Exp Eye Res. 1995;60(4):359-71. doi: 10.1016/s0014-4835(05)80093-4.

12. Kramer TR, Noecker RJ. Comparison of the morphologic changes after selective laser trabeculoplasty and argon laser trabeculoplasty in 
Annals of International Medical and Dental Research E-ISSN: 2395-2822 | P-ISSN: 2395-2814

Vol-8, Issue-2 | March-April 2022

DOI: 10.53339/aimdr.2022.8.2.19

Page no- 135-144 | Section- Research Article (Haematology)

human eye bank eyes. Ophthalmology. 2001;108(4):773-9. doi: 10.1016/s0161-6420(00)006606.

13. Latina MA, Sibayan SA, Shin DH, Noecker RJ, Marcellino G. Q-switched 532-nm Nd:YAG laser trabeculoplasty (selective laser trabeculoplasty): a multicenter, pilot, clinical study. Ophthalmology. 1998;105(11):2082-8. doi: 10.1016/S01616420(98)91129-0.

14. Kajiya S, Hayakawa K, Sawaguchi S. Clinical Results of Selective Laser Trabeculoplasty. Jpn J Ophthalmol. 2000;44(5):574-575. doi: 10.1016/s0021-5155(00)00229$\mathrm{x}$.

15. Gracner T. Intraocular pressure response to selective laser trabeculoplasty in the treatment of primary open-angle glaucoma. Ophthalmologica. 2001;215(4):267-70. doi: 10.1159/000050872.

16. Gracner T. Intraocular pressure response of capsular glaucoma and primary open-angle glaucoma to selective Nd:YAG laser trabeculoplasty: a prospective, comparative clinical trial. Eur J Ophthalmol. 2002;12(4):287-92.

17. Cvenkel B. One-year follow-up of selective laser trabeculoplasty in open-angle glaucoma. Ophthalmologica. 2004;218(1):20-5. doi: 10.1159/000074562.

18. Lai JS, Chua JK, Tham CC, Lam DS. Five-year follow up of selective laser trabeculoplasty in Chinese eyes. Clin Exp Ophthalmol. 2004;32(4):368-72. doi: 10.1111/j.1442-9071.2004.00839.x.

19. Francis BA, Ianchulev T, Schofield JK, Minckler DS. Selective laser trabeculoplasty as a replacement for medical therapy in open-angle glaucoma. Am J Ophthalmol. 2005;140(3):524-5. doi: 10.1016/j.ajo.2005.02.047.

20. Juzych MS, Chopra V, Banitt MR, Hughes BA, Kim C, Goulas MT, et al. Comparison of long-term outcomes of selective laser trabeculoplasty versus argon laser trabeculoplasty in open-angle glaucoma. Ophthalmology. 2004;111(10):1853-9. doi: 10.1016/j.ophtha.2004.04.030.

21. Damji KF, Shah KC, Rock WJ, Bains HS, Hodge WG. Selective laser trabeculoplasty $\mathrm{V}$ argon laser trabeculoplasty: a prospective randomised clinical trial. Br J Ophthalmol. 1999;83(6):718-22. doi: 10.1136/bjo.83.6.718.

22. Damji KF, Bovell AM, Hodge WG, Rock W, Shah K, Buhrmann $R$, et al. Selective laser trabeculoplasty versus argon laser trabeculoplasty: results from a 1year randomised clinical trial. $\mathrm{Br} \mathrm{J}$ Ophthalmol. 2006;90(12):1490-4. doi: 10.1136/bjo.2006.098855.

23. Olthoff CM, Schouten JS, van de Borne BW, Webers CA. Noncompliance with ocular hypotensive treatment in patients with glaucoma or ocular hypertension an evidence-based review. Ophthalmology. 2005;112(6):953-61. doi: 10.1016/j.ophtha.2004.12.035.

24. Stewart WC, Konstas AG, Pfeiffer N. Patient and ophthalmologist attitudes concerning compliance and dosing in glaucoma treatment. J Ocul Pharmacol Ther. 2004;20(6):461-9. doi: 10.1089/jop.2004.20.461.

25. Nordstrom BL, Friedman DS, Mozaffari E, Quigley HA, Walker AM. Persistence and adherence with topical glaucoma therapy. Am J Ophthalmol. 2005;140(4):598-606. doi: 10.1016/j.ajo.2005.04.051.

26. Robin AL, Covert D. Does adjunctive glaucoma therapy affect adherence to the initial primary therapy? Ophthalmology. 2005;112(5):863-8. doi: 10.1016/j.ophtha.2004.12.026.

27. Brandt JD, Wittpenn JR, Katz LJ, Steinmann WN, Spaeth GL. Conjunctival impression cytology in patients with glaucoma using long-term topical medication. Am J Ophthalmol. 1991;112(3):297-301. doi: 10.1016/s0002-9394(14)76730-3.

28. Broadway DC, Grierson I, O'Brien C, Hitchings RA. Adverse effects of topical antiglaucoma medication. II. The outcome of filtration surgery. Arch Ophthalmol. 1994;112(11):1446-54. doi: 10.1001/archopht.1994.01090230060021.

29. The Advanced Glaucoma Intervention Study (AGIS): 4. Comparison of treatment outcomes within race. Seven-year results. Ophthalmology. 1998;105(7):114664. doi: 10.1016/s0161-6420(98)97013-0.

30. Richter CU, Shingleton BJ, Bellows AR, Hutchinson BT, Jacobson LP. Retreatment with argon laser trabeculoplasty. Ophthalmology. 1987;94(9):1085-9. doi: 10.1016/s0161-6420(87)33319-6.

31. Grayson DK, Camras CB, Podos SM, Lustgarten JS. Long-term reduction of intraocular pressure after repeat argon laser trabeculoplasty. Am J Ophthalmol. 1988;106(3):312-21. doi: 10.1016/0002-9394(88)903674.

32. Latina MA, Gulati V. Selective laser trabeculoplasty: stimulating the meshwork to mend its ways. Int Ophthalmol Clin. 2004;44(1):93-103. doi: 10.1097/00004397-200404410-00011. 
Annals of International Medical and Dental Research

E-ISSN: 2395-2822 | P-ISSN: 2395-2814

Vol-8, Issue-2 | March-April 2022

DOI: $10.53339 /$ aimdr.2022.8.2.19

Page no- 135-144 | Section- Research Article (Haematology)

33. Melamed S, Ben Simon GJ, Levkovitch-Verbin H. Selective laser trabeculoplasty as primary treatment for open-angle glaucoma: a prospective, nonrandomized pilot study. Arch Ophthalmol. 2003;121(7):957-60. doi: 10.1001/archopht.121.7.957.

34. van der Valk R, Webers CA, Schouten JS, Zeegers MP, Hendrikse F, Prins MH. Intraocular pressurelowering effects of all commonly used glaucoma drugs: a meta-analysis of randomized clinical trials. Ophthalmology. 2005;112(7):1177-85. doi: 10.1016/j.ophtha.2005.01.042.

35. Mcllraith I, Strasfeld M, Colev G, Hutnik CM. Selective laser trabeculoplasty as initial and adjunctive treatment for open-angle glaucoma. J Glaucoma. 2006;15(2):124-30. doi: 10.1097/00061198200604000-00009.
36. Quinn MP, Johnson D, Whitehead M, Gill SS, Campbell RJ. Predictors of Initial Glaucoma Therapy with Laser Trabeculoplasty versus Medication: A Population-Based Study. Ophthalmol Glaucoma. 2021;4(4):358-364. doi: 10.1016/j.ogla.2020.11.001. Epub 2020 Dec 21.

37. De Keyser M, De Belder M, De Groot V. Selective laser trabeculoplasty in pseudophakic and phakic eyes: a prospective study. Int J Ophthalmol. 2017;10(4):593-598. doi:10.18240/ijo.2017.04.15

Source of Support: Nil, Conflict of Interest: None declared 